\title{
EDUKASI DAN PELATIHAN SIMULASI TANGGAP DARURAT BENCANA KEBAKARAN BAGI SANTRI DI BANYUWANGI
}

\author{
Erna Suryani ${ }^{1^{*}}$, Wahyu Naris Wari ${ }^{2}$, Siska Aprilia $\mathrm{H}^{3}$ \\ ${ }_{1,2,3}$ Prodi Teknik Sipil, Politeknik Negeri Banyuwangi, Indonesia \\ erna@poliwangi.ac.id ${ }^{1}$, naris@poliwangi.ac.id ${ }^{3}$, siska_aprilia3@poliwangi.ac.id ${ }^{3}$
}

\begin{abstract}
ABSTRAK
Abstrak: Pondok pesantren Darussholah Singojuruh telah berusia puluhan tahun rentan terjadi kecelakaan atau keadaan darurat, misalkan kebakaran. Dengan banyaknya santri yang tinggal dan penggurus pesantren yang berjumlah 300 orang lebih, maka perlu adanya penyiapan jika terjadi keadaan darurat. Keadaan Darurat didefinisikan sebagai keadaan sulit yang tidak diduga yang memerlukan penanganan segera supaya tidak terjadi kecelakaan/kefatalan. Dalam kegiatan edukasi dan simulasi tanggap darurat kebakaran ini akan dilakukan edukasi berupa pembekalan materi tentang hal-hal yang menyebabkan kebakaran, material-material yang mudah terbakar, dan bagaimana penanggulangan bahaya kebakaran jika terjadi. Setelah dilakukan edukasi mengenai kebakaran akan dilaksanakan simulasi tanggap darurat yang meliputi santri pondok pesantren sebagai peserta sehingga jika terjadi suasana tanggap darurat kebakaran akan mudah untuk mengatasi kondisi tersebut agar tidak menyebabkan kerusakan yang parah pada pondok pesantren apalagi sampai menimbulkan korban manusia. Dalam simulasi ini dilakukan pula pelatihan penggunaan APAR. Hal ini sebagai salah satu penerapan pada bidang Keselamatan dan Kesehatan Kerja (K3) di Pondok Pesantren Darussholah Singojuruh. Sebelum diadakan kegiatan edukasi dan pelatihan ini santri tidak mengetahui bagaimana cara penangganan yang tepat jika terjadi kondisi darurat kebakaran, sehingga keberhasilan kegiatan ini dapat dikatakan $100 \%$ berhasil karena setelah kegiatan mereka mengetahui bagaimana menangani bahaya kebakaran termasuk penggunaan APAR.
\end{abstract}

Kata Kunci: Tanggap Darurat; Kebakaran; K3; APAR.

\begin{abstract}
Darussholah Singojuruh Islamic boarding school is decades old prone to accidents or emergencies, for example fires. With the number of santri living and boarding school officials totaling more than 300 people, it is necessary to prepare in case of an emergency. Emergency is defined as an unexpectedly difficult situation that requires immediate treatment to prevent accidents / fatalities. In this educational activity and fire emergency response simulation, education will be conducted in the form of provisioning material on matters that cause fires, flammable materials, and how to deal with fire hazards if they occur. After conducting education about the fire, an emergency response simulation will be conducted which includes the students of the Islamic boarding school as participants so that if there is an emergency response situation, the fire will be easy to overcome these conditions so as not to cause severe damage to the boarding school especially to cause human casualties. In this simulation also conducted training on the use of APAR. This is as one of the applications in the field of Occupational Safety and Health (K3) in Darussholah Singojuruh Islamic Boarding School. Before the education and training activities were held, students did not know how to subscribe properly in the event of a fire emergency, so the success of this activity could be said to be 100\% successful because after their activities they knew how to deal with fire hazards including the use of fire extinguisher.
\end{abstract}

Keywords: Emergency Response;Fire; K3; APAR. 


\section{A. LATAR BELAKANG}

Keadaan darurat dapat terjadi kapanpun dan dimanapun tanpa terkecuali. Dengan adanya pemicu dan kondisi yang memungkinkan maka keadaan darurat dapat menyebabkan kerugian yang tidak sedikit (Siswanto, 2012), (Yuniar, Mahrur, \& Sarwono, 2016). Di Pondok Pesantren Darussholah Singojuruh yang telah berusia puluhan tahun dapat mengalami kecelakaan atau keadaan darurat berupa kebakaran. Dengan banyaknya santri yang tinggal dan pengurus pesantren yang berjumlah ratusan orang lebih, maka perlu adanya persiapan jika terjadi keadaan darurat kebakaran sewaktu-waktu. Keadaan Darurat berupa kebakaran ini jika terjadi dapat menyebabkan kerugian yang besar jika tidak tertangani dengan tepat dan segera, karena sangat mungkin kerugian tidak hanya menyangkut secara materi namun juga dapat menimbulkan korban jiwa (Ayu et al., 2013), (Linuwih, 2015).

Berdasarkan survey yang telah dilakukan di lokasi, pengetahuan tentang penanggulangan kondisi darurat khususnya kebakaran belum dikuasai oleh khususnya para santri di pondok pesantren. Oleh karena itu pengetahuan tentang penanganan jika terjadi bahaya kebakaran pada Pondok Pesantren Darussholah Singojuruh Kabupaten Banyuwangi memerlukan perhatian, karena jika terjadi kebakaran kerugiannya bisa sangat besar. Berdasarkan latar belakang tersebut, maka dilaksanakanlah kegiatan yang merupakan perwujudan dari program pengabdian masyarakat dengan judul "Edukasi dan Pelatihan Simulasi Tanggap Darurat Bencana Kebakaran di Pondok Pesantren Darussholah Singojuruh Kabupaten Banyuwangi”. Dalam kegiatan ini dilakukan edukasi dan simulasi jika terdapat keadaan darurat kebakaran yang terjadi di Pondok Pesantren Darussholah Singojuruh Kabupaten Banyuwangi. Hal ini perlu sekali dilakukan mengingat banyaknya santri yang tinggal dan menuntut ilmu di tempat tersebut.

\section{B. KAJIAN PUSTAKA}

Bangunan yang ada di Indonesia yang merupakan fasilitas bersama yang sebagian besar berupa bangunan bertingkat minimum lantai 2. Hal ini terkait dengan ketersediaan lahan. Bangunan bertingkat tinggi sangat merebak pembangunannya terutama di kawasan perkotaan, baik sebagai hunian, perkantoran, pusat perbelanjaan maupun tempat rekreasi. Bangunan bertingkat tinggi tentu memiliki jumlah penghuni ataupun pengguna yang tidak sedikit apalagi jika bangunan tersebut berfungsi pula sebagai ruang publik. Dengan demikian keselamatan para penggunanya tentu harus diutamakan dan tidak dapat diabaikan (Paiton, Ytl, Kristianingsih, \& Proses, 2013), (Kowara, 2017).

\section{Keadaan Darurat}

Keadaan darurat merupakan suatu kondisi tidak normal yang mendadak, mengganggu kegiatan dan perlu segera ditangani (Ramli, 2010). Pada dasarnya keadaan darurat ini perlu dipersiapkan tentang bagaimana cara mengatasinya.

Sistem manajemen tanggap darurat sangat berkaitan dengan sistem pencegahan dan penanggulangan kebakaran di gedung. Salah satu sistem pencegahan dan penanggulangan kebakaran adalah sistem proteksi aktif 
dan sistem proteksi pasif. Setiap bangunan harus dilengkapi dengan sarana dan prasarana penyelamat diri yang dapat digunakan oleh penghuni bangunan, sehingga apabila terjadi keadaan darurat kebakaran penghuni dapat menyelamatkan diri dengan aman (Suma'mur P.K, 2009). Definisi Unit Tanggap Darurat ialah unit kerja yang dibentuk secara khusus untuk menanggulangi keadaaan darurat di tempat kerja. Unit kerja tersebut dibentuk dengan tujuan untuk memenuhi persyaratan OHSAS 18001:2007 klausul 4.4.7 Emergency Preparedness and Response (Persiapan Tanggap Darurat). Bagian dari perencanaan untuk memenuhi klausul OHSAS 18001:2007 4.4.7. kondisi tersebut antara lain :

a. Kebakaran yang tidak mampu dipadamkan Regu Pemadam Kebakaran Perusahaan dalam waktu singkat.

b. Peledakan spontan pada peralatan listrik.

c. Kebocoran gas/cairan/bahan material berbahaya lainnya dalam skala besar dan tidak bisa diatasi dalam waktu singkat.

d. Bencana alam di lingkungan Perusahaan (Gempa Bumi, Angin Ribu, $\mathrm{dsb}$.

e. Terorisme (Ancaman Bom, Perampokan, dan sebagainya).

f. Demonstrasi/Unjuk Rasa/Huru-hara di dalam/di luar lingkungan Perusahaan.

g. Kecelakaan / Keracunan Massal.

\section{Kebakaran}

Menurut Peraturan Menteri Nomor 04/MEN/1980 kebakaran diklasifikasikan menjadi 4, yaitu kategori A,B,C,D. dimana katagori A adalah kebakaran benda benda padat kecuali logam, contohnya kayu, kertas dan plastik. Kategori B adalah kebakaran benda bahan bakar cair atau gas, contohnya kerosene, bensin, LPG dan minyak. Kategori C adalah kebakaran suatu instalasi listrik, contohnya breaker listrik, peralatan alat elektronik. Kategori D adalah kebakaran pada benda-benda logam, seperti magnesium, alumunium, natrium. Sedangkan menurut NFPA kebakaran diklasifikasikan menjadi 6, yaitu A,B,C,D,E dan K. Pengertian kebakaran A,B,C,D sama seperti pada PERMEN no.04/MEN/1980. Kategori E,yaitu kebakaran yang disebabkan oleh suatu bahan-bahan radioaktif. Kebakaran kategori $\mathrm{K}$ adalah kebakaran yang disebabkan bahan akibat konsentrasi lemak yang tinggi. Kebakaran ini banyak terjadi di dapur. Api yang timbul di dapur dapat dikategorikan pada api kelas B.

Melihat bahaya yang dapat terjadi akibat bahaya kebakaran ini, standar operasional prosedur (SOP) tentang penanggulangan darurat kebakaran diberikan untuk memenuhi peraturan dari Kepmenaker No. 186 tahun 1999.

\section{METODE PELAKSANAAN}

Lokasi kegiatan ini berada di Pondok Pesantren Darussholah Singojuruh Kabupaten Banyuwangi, dimana pondok pesantren ini merupakan salah satu tempat pendidikan agama Islam yang mana peserta didiknya tinggal di Pondok Pesantren Tersebut. Berdirinya Pondok Pesantren Darussholah Singojuruh,adalah merupakan bagian dari kisah nyata yang diilhami dari tokoh Ulama' Besar di Banyuwangi KH. 
Mukhtar Syafa'at Abdul Ghofur Pendiri dan Pengasuh Pondok Pesantren Darussalam Blok Agung.

Pada tanggal 17 April 1988 M Pondok Pesantren Darussholah di dirikan. Dengan berjalannya waktu Pondok Pesantren Darussholah mengalami perkembangan dengan bertambahnya jumlah santri yang menuntut ilmu di Pondok Pesantren. Kemudian pada tanggal tersebut pula didirikan Yayasan dengan nama "Yayasan Darussholah" yang menjadi naungan dari segala aktifitas di Pondok Pesantren. Pada tanggal 22 Juni 2003 diresmikan berdirinya SMA Negeri Darussholah Singojuruh yang berlokasi di samping Pondok Pesantren. Dengan berdirinya SMA Negeri Darussholah Singojuruh ini memenuhi kebutuhan akan pendidikan formal khususnya di masyarakat Singojuruh pada tingkat menengah atas.

Peserta dari kegiatan ini adalah para santri yang tinggal di pondok pesantren yang berjumlah 300 orang lebih. Dalam pelaksanaan kegiatan "Edukasi Dan Pelatihan Simulasi Tanggap Darurat Bencana Kebakaran Di Pondok Pesantren Darussholah Singojuruh Kabupaten Banyuwangi “ ini dilakukan beberapa kegiatan. Kegiatan tersebut adalah sebagai berikut:

\section{Survey Lokasi Pondok Pesantren}

Kegiatan ini bertujuan untuk mengetahui seberapa besar potensi bahaya kebakaran yang dapat terjadi di lapangan, agar kegiatan dapat berlangsung dengan efektif dan efisien. Selain itu dalam kegiatan ini dilakukan wawancara dengan pengurus pondok pesantren tentang pengetahuan pengurus pondok pesantren khususnya jika terjadi bahaya kebakaran.

\section{Edukasi Tentang Bahaya Kebakaran}

Dalam edukasi ini diberikan materi kepada para peserta yang merupakan penghuni Pondok Pesantren tentang hal-hal yang menyebabkan kebakaran, material-material yang mudah terbakar, dan bagaimana penanggulangan bahaya kebakaran jika terjadi khususnya di pondok pesantren. Peserta dalam kegiatan ini selain santri dari pondok pesantren juga pengurus pondok pesantren itu sendiri. Sehingga jika terjadi bahaya kebakaran para penghuni baik santri maupun pengurus bias tenang dalam menghadapi kebakaran, tidak malah panik atau binggung mau melakukan apa ketika bahaya terjadi.

\section{Pelatihan Simulasi Tanggap Darurat Kebakaran}

Dalam simulasi ini dilakukan pelatihan penggunaan Alat Pemadam Api Ringan (APAR). Sehingga jika ada kebakaran kecil tidak sampai menyebabkan kerusakan yang besar bagi penghuni pondok pesantren.

\section{HASIL DAN PEMBAHASAN}

Kegiatan Pengabdian kepada masyarakat telah dilaksanakan dengan berbagai bentuk kegiatan berupa sosialisasi dan simulasi tanggap darurat terhadap bahaya kebakaran khususnya di Pondok Pesantren Darussholah Singojuruh Kabupaten Banyuwangi. Adapun keluaran yang dicapai (output) adalah sebagai berikut:

\section{Survei Lokasi}

Berdasarkan hasil survey yang telah dilakukan sebelumnya, diperoleh beberapa permasalahan yang dihadapi oleh mitra seperti yang telah dipaparkan dalam latar belakang. Dari berbagai permasalahan yang ada, 
solusi untuk mengatasi permasalahan yang ada dengan cara mengadakan pemberian edukasi berupa sosialisasi dan simulasi terhadap santri dan pengurus pondok pesantren Darussholah Singojuruh Kabupaten Banyuwangi. Pada tahap ini dilakukan perizinan dan sekaligus survei lokasi di Pondok Pesantren pada tanggal 16 September 2019. Pengusul melakukan survei lokasi di lokasi pondok pesantren putra dan putri. Pusat kegiatan keagamaan, kegiatan formal maupun kegiatan non formal dilakukan disekitar masjid pondok pesantren Darussholah.

\section{Pemberian Edukasi (Sosialisasi) mengenai Tanggap Darurat Bencana Kebakaran}

Kegiatan sosialisasi atau pemberian edukasi berupa tanggap darurat kebakaran dilakukan pada tanggal 21 September 2019 pukul 08.30 sampai 11.00 WIB di Pondok Pesantren Putri Darussholah Singojuruh. Peserta sosialisasi sebanyak 50 santri putri.. Narasumber sosialisasi adalah Ibu Erna Suryani selaku ketua tim PKM. Kegiatan edukasi ini seperti terlihat pada Gambar 1 berikut.

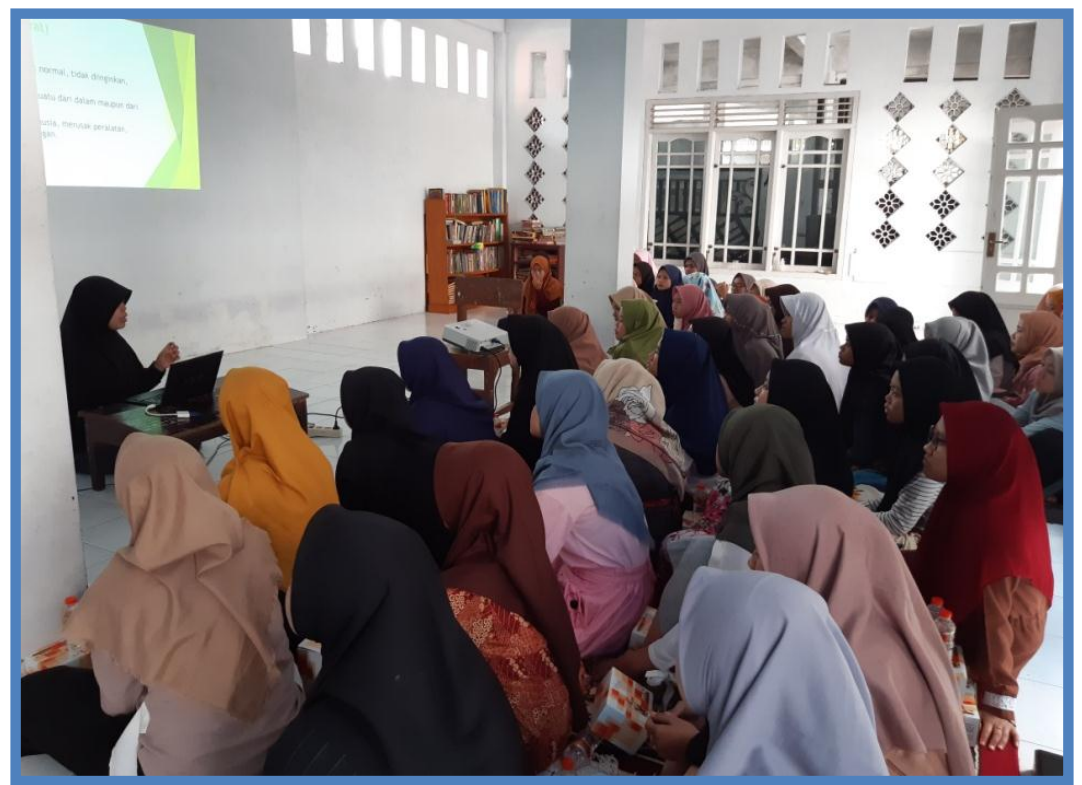

Gambar 1. Sosialisasi Tanggap Darurat terhadap Kebakaran

Kegiatan edukasi atau sosialisasi ini dilakukan dengan memberikan pembekalan materi tentang hal-hal yang menyebabkan kebakaran, material-material yang mudah terbakar, dan bagaimana penanggulangan bahaya kebakaran jika terjadi. Setelah pemberian materi selesai, narasumber menunjukkan berbagai alat-alat yang dibutuhkan dalam menghadapi bahaya kebakaran serta memberikan contoh penggunaan alatalat tersebut.

\section{Pelatihan Berupa Simulasi Tanggap Darurat Bencana Kebakaran}

Setelah dilakukan edukasi mengenai hal-hal yang menyebabkan kebakaran, material-material yang mudah terbakar, dan bagaimana penanggulangan bahaya kebakaran jika terjadi selanjutnya dilaksanakan simulasi tanggap darurat kebakaran pada tanggal 22 September 2019 yang meliputi 60 santri pondok pesantren dan pengurus sebagai peserta sehingga jika terjadi suasana tanggap darurat kebakaran akan mudah untuk mengatasi kondisi tersebut agar tidak menyebabkan kerusakan yang parah pada pondok pesantren apalagi sampai menimbulkan korban manusia. 
Dalam simulasi ini dilakukan pula pelatihan penggunaan APAR. Hal ini sebagai salah satu penerapan pada bidang Keselamatan dan Kesehatan Kerja (K3) di Pondok Pesantren Darussholah Singojuruh. Simulasi dilakukan oleh tim teknisi dari Teknik Sipil yaitu bapak Muhendra dan 1 mahasiswa Politeknik Negeri Banyuwangi yaitu Andi Wahyu Sanjaya.

Pada simulasi diberikan api kecil dan peserta disuruh untuk memadamkan api tersebut dengan menggunakan APAR. Peserta diberikan rompi safety vest, helm, dan masker saat melakukan simulasi. Hal ini sesuai dengan penerapan bidang Keselamatan dan Kesehatan Kerja (K3). Diakhir simulasi, dilakukan serah terima perlengkapan/ alat-alat yang dibutuhkan dalam menghadapi bahaya kebakaran berupa APAR, helm, rompi, dan masker. Kegiatan ini seperti terlihat pada Gambar 2 berikut.

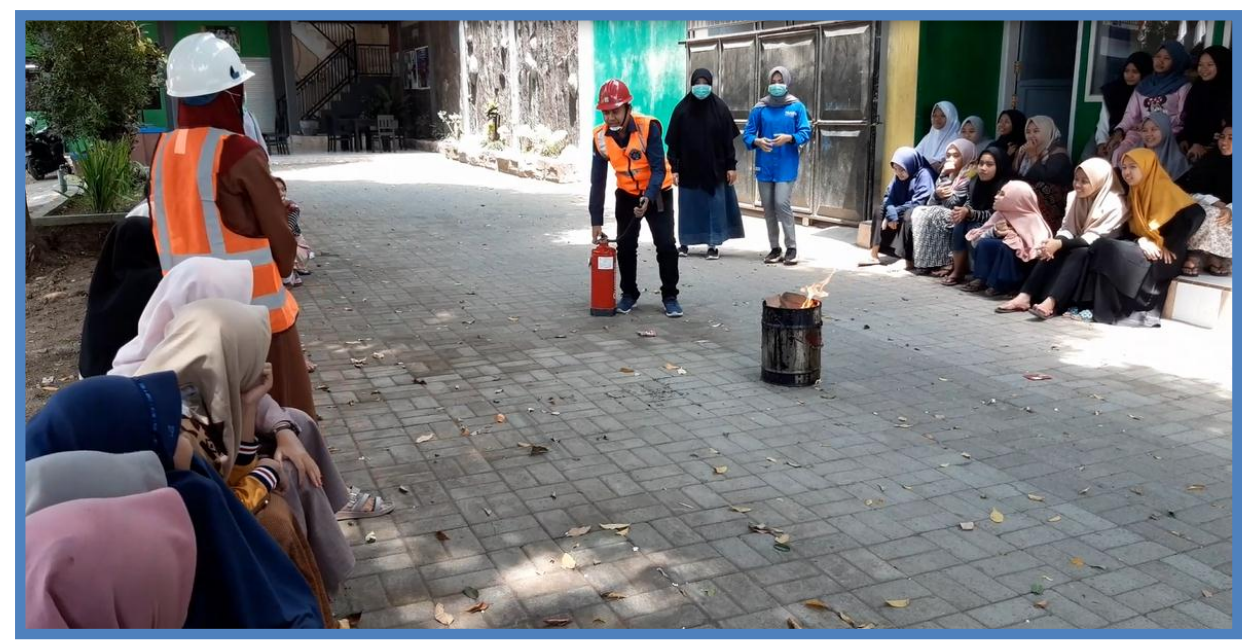

Gambar 2. Simulasi Tanggap Darurat Bahaya Kebakaran

\section{E. SIMPULAN DAN SARAN}

Berdasarkan hasil pelaksanaan kegiatan pengabdian masyarakat di Pondok Pesantren Darussholah Singojuruh Kabupaten Banyuwangi, dapat disimpulkan beberapa hal diantaranya kegiatan ini khususnya pada sosialisasi, secara umum meningkatkan pengetahuan mengenai kebakaran baik dari segi penyebab, material-material yang mudah terbakar, dan penanggulangan jika terjadi bahaya kebakaran. Selain itu pada kegiatan ini mampu meningkatkan keterampilan dalam penggunaan alat-alat pemadam kebakaran khususnya Alat Pemadam Api Ringan (APAR). Serta dalam pelaksanaan di lapangan para peserta yaitu santri putri pondok pesantren Darussholah Singojuruh memberikan tanggapan yang baik dan antusias yang tinggi atas program yang dilakukan.

Saran yang dapat diberikan berdasarkan hasil kegiatan pengabdian ini yaitu perlu adanya pengembangan lebih lanjut terkait tim ahli di bidang penanganan kebakaran agar pengetahuan lebih dalam mengenai tanggap darurat kebakaran serta pengunaan alat-alat lain dalam penanganan darurat kebakaran.

\section{UCAPAN TERIMA KASIH}

Terima kasih kami berikan kepada pihak-pihak yang telah membantu terlaksananya kegiatan ini, karena atas kerjasama dan dukungan yang 
diberikan kegiatan ini berjalan dengan baik yakni (1) Lembaga Pusat Penelitian dan Pengabdian Masyarakat Politeknik Negeri Banyuwangi hang telah mendanai kegiatan pengabdian ini sehingga kegiatan ini dapat berlangsung dengan lancar; dan (2) Seluruh pengurus dan peserta pelatihan dari Pondok Pesantren Darussholah.

\section{DAFTAR RUJUKAN}

Ayu, M., Fatma, P., Ridwansyah, L., Keselamatan, D., Fakultas, K., Masyarakat, K., ... Universitas, I. (2013). Emergency Response System Implementation Analysis Base on National Fire Protection Association 1600. Kesmas: National Public Health Journal, 7(10), 435-439.

Kowara, R. A. (2017). Analisis Sistem Proteksi Kebakaran Sebagai Upaya Pencegahan Dan Penanggulangan Kebakaran. Jurnal Manajemen Kesehatan Yayasan RS.Dr. Soetomo, 3(1), 69. https://doi.org/10.29241/jmk.v3i1.90

Linuwih, R. M. (2015). Faktor-Faktor Yang Mempengaruhi Kesiapsiagaan Tanggap Darurat Kebakaran Pada Penghuni Mess Pt. Sango Indonesia Semarang. Fakultas Kesehatan, 0-1.

Paiton, P., Ytl, P. T., Kristianingsih, L., \& Proses, A. S. (2013). Analisis Safety System dan Manajemen Risiko pada Steam Boiler PLTU di Unit 5. Jurnal Teknik POMITS, 2(2), 2-7.

Ramli, S. (2010). Manajemen Kebakaran. Computers \& Education. https://doi.org/10.1145/2505515.2507827

Siswanto, L. (2012). Sistem Informasi Manajemen Komando Tanggap Darurat Bencana Letusan Gunung Merapi. Jurnal Teknologi Informasi, 7(19), 15-24.

Suma'mur P.K. (2009). Higiene Perusahaan dan Kesehatan Kerja (HIPERKES). In Jakarta : Sagung Seto.

Yuniar, I., Mahrur, A., \& Sarwono. (2016). Faktor-Faktor yang Mempengaruhi Lamanya Waktu Tanggap dalam Pelayanan Gawat Darurat di Instalasi Gawat Darurat RSUD Dr Soedirman Kebumen. Jurnal Ilmiah Kesehatan Keperawatan. 